\title{
Metacognitive Instruction Does Improve Listening Comprehension
}

\author{
Hossein Bozorgian \\ Queensland University of Technology, Faculty of Education, Centre for Learning Innovation, Brisbane, QLD 4059, Australia \\ Correspondence should be addressed to Hossein Bozorgian, h.bozorgian@qut.edu.au
}

Received 7 December 2011; Accepted 26 February 2012

Academic Editors: B. W. Baldwin and H. Weizman

Copyright () 2012 Hossein Bozorgian. This is an open access article distributed under the Creative Commons Attribution License, which permits unrestricted use, distribution, and reproduction in any medium, provided the original work is properly cited.

This paper reports on a small-scale study, which looked into the impact of metacognitive instruction on listeners' comprehension. Twenty-eight adult, Iranian, high-intermediate level EFL listeners participated in a "strategy-based" approach of advance organisation, directed attention, selective attention, and self-management in each of four listening lessons focused on improving listeners' comprehension of IELTS listening texts. A comparison of pretest and posttest scores showed that the "less-skilled" listeners improved more than "more-skilled" listeners in the IELTS listening tests. Findings also supported the view that metacognitive instruction assisted listeners in considering the process of listening input and promoting listening comprehension ability.

\section{Introduction}

Listening comprehension, a basic skill is a challenge for both English as a Foreign Language (EFL) listeners and instructors. This challenge arising may lead to frustration, poor listeners' performance, or inadequate attention paid in the classroom. This is because listening comprehension input is implicit and complex and needs a listening lesson aligning with a strategy-based approach to control the input. The complexity of listening may involve external factors related to speaker, text, and/or content. These factors, new expressions, speech rate, accent, unfamiliar content, and cultural references, increase the difficulty of listening message being understood [1]. To reduce the complexity of listening comprehension for less-skilled listeners, "metacognitive instruction" is used to develop and facilitate the process of listening comprehension.

\section{Metacognitive Instruction in Listening}

The term "metacognition" is often simplified as thinking about thinking or cognition about cognition. Flavell [2] first coined the term metacognition and defined it "knowledge concerning one's own cognitive processes and products or anything related to them." Flavell [2] deconstructed this into three different kinds of metacognitive knowledge:

(i) person knowledge (the knowledge a person has about him or herself and others as cognitive processors),

(ii) task knowledge (the knowledge a person has about the information and resources they need to undertake a task),

(iii) strategy knowledge (knowledge regarding the strategies which are likely to be effective in achieving goals and undertaking tasks).

Wenden [3] suggests that metacognitive knowledge is a stable body of knowledge, though, of course, it may change over time as one acquires cognitive maturity and experience. As is the case with other aspects of socialisation, this knowledge may often be acquired unconsciously through observation and imitation or consciously as learners listen to teachers, parents, or peers providing them with advice about how to learn. As such, Davidson and Sternberg [4] maintain that metacognitive knowledge allows problem solvers to better encode and represent the assumptions in a problem context and therefore better perform. There has been a growing interest for almost two decades in using metacognitive instruction to facilitate the outcome of listening. Increasing better performance of less-skilled listeners requires following 
a strategy-based approach, a set of rules and regular opportunities to tackle listening problems strategically. Listeners are to be provided with enough opportunities to act upon the set of rules already devised by the instructor. This regulated procedure helps listeners to plan, monitor, and evaluate their listening $[5,6]$. The pedagogical evidence from the study [7] shows that metacognitive instruction assists listeners in (i) what successful listeners choose to select for processing and (ii) improving successful language learning through acquiring metacognitive strategies. One such way is to take the process of listening that involves listeners with a listening lesson consisting advance organisation, directed attention, selective attention, and self-management. The sequence of listening tasks helps listeners analyse the listening input further to understand the message.

\section{A Strategy-Based Approach}

Mendelsohn [8] coined the term a "strategy-based" approach and proposed that the classroom curriculum for a listening course should include instructing listeners about listening strategies. Listening strategy instruction functions as "spinal cord" or pillars upon which a listening course is built. Mendelsohn [8] defines a "strategy-based" approach as follows:

A strategy-based approach, then, is a methodology that is rooted in strategy training .... It is an approach that sees the objective of the English as a Second Language (ESL) course as being to train students how to listen, by making learners aware of the strategies that they use, and training them in the use of additional strategies that will assist them in tackling listening tasks .... Learners have to be weaned away from strategies that are unhelpful or even destructive, like grabbing for a dictionary..., and these have to be replaced by such helpful strategies as guessing the meaning of a word from the context.

The materials used in a listening lesson should feature authentic and natural everyday speech. Field [9] suggests that listening lessons at beginner, elementary, and intermediate level should be authentic and take the following two points into considerations. First, listeners should be carefully briefed so that they feel comfortable about being exposed to listening texts where they may have problems to understand the message. Second, instructors should grade the difficulty of tasks to fit to the comprehension level of the listeners rather than grading the text so that listeners would be able to achieve it.

Three-classroom-base research, which has focused on the strategy-based approach, has indicated that metacognitive instruction improves less-skilled listeners' performance. First, Cross [10] conducted a small-scale study of the effect of metacognitive instruction on a group of twenty Japanese advanced EFL listeners' comprehension over five listening lessons. The results from pretest and posttest scores illustrate that three of four less-skilled listeners made substantial gains across five lessons, whereas only one of four more-skilled listeners improved. Second, Vandergrift and Tafaghodtari [5] measured the listening comprehension of 106 tertiary-level high-beginner and lower-intermediate learners of French as an L2 over a semester. The findings from a pretest and posttest scores show that the less-skilled listeners participated in the guided methodology (strategy-based) made greater gains than more-skilled peers. Finally, Goh and Taib [11] conducted a small-scale study to assess the development of a group of ten Chinese primary school, ESL listeners over eight listening lessons. The results from a pretest and posttest indicated that the less-skilled listeners reported increased motivation, confidence and strategy knowledge and one of the more-skilled listeners failed to improve across the study. The findings of the studies above show that a strategy-based approach in the classroom is effective for listeners to develop listening comprehension.

\section{Research Focus}

Given the significance of metacognitive instruction as an indicator of listening development, the aim of this smallscale study is to find out where metacognitive instruction benefits less-skilled EFL listeners' comprehension. To achieve this aim and follow the taxonomy [7], the listeners' performance in International English Language Testing System (IELTS) listening tests in pretest and posttest are compared in terms of the number of correct answers. The instructor guided through four listening lessons based on the recorded listening texts of the daily conversation (lesson one), public speech (lesson two), academic discussion (lesson three), and academic lecture (lesson four). The focus of the listening lessons was one way, and all classroom interactions were conducted in English. The listeners were directed and encouraged to use metacognitive strategies (advance organisation, directed attention, selective attention, and selfmanagement) when approaching the recorded listening texts. The listeners were interviewed briefly at the end of the study about (1) their perception of the listening lessons focused on the process of listening comprehension and (2) the significance of listening comprehension in English language learning.

4.1. Participants. A group of 28 Iranian males aged between 17 and 24 years took part in this study. Out of the total 30 enrolments for this class, two listeners declined to take part in either the pretest or posttest listening administration. All were attending a high-intermediate level English language course based on the English language institute, which is nearly equivalent to IELTS 6. Metacognitive instruction was not in practice for the listeners in their regular classroom in the English language institute. Listeners themselves chose their learning partners to practise the listening activities in a group. Pseudonyms were used for listeners in this study.

4.2. Materials. The listening materials used in each of the lessons were based on the recoded IELTS listening texts. The choice of the IELTS listening texts was based on the view 
that the high-intermediate listeners participated in this study intended to take the IELTS test in near future. The purpose of their English language learning was to continue their further education in one of the English countries. All the recorded IELTS listening texts for the four lessons were approximately from one and a half to two and a half minutes long and presented on an audio CD player in short segments.

4.3. Acting out the Lessons. Each of the four listening lessons was 70 minutes long and involved a strategy-based approach [12]. The sequence of the tasks based on the study [13] consists of three main phases, and the strategy-based approach is described below.

(1) Listening: in this phase, listeners

(a) listen, without notetaking, to short text spoken at normal speed,

(b) self-assess their comprehension level,

(c) listen two more times while taking notes.

(2) Reconstructing: in this phase listeners

(a) form small groups and use their notes to attempt to reconstruct the text.

(3) Discovery: in this phase students

(a) compare their text with the original and attempt to classify the causes of mistakes,

(b) assess the relative importance of their errors,

(c) listen again without reading the text and assess their performance.

In phase one, listeners were familiar with the topic of the discussion while they were assessing their comprehension level for the first time listening. This topic familiarity functions as the advance organization helping listener to direct the attention to the content of the listening texts. Then, listeners listened to the same recorded listening text two more times and at the same time took some notes. Taking notes assisted listeners in improving the selective attention. Taking notes helped listeners to increase their working memory capacity to embrace more listening input led to further understanding. After listening to the text for three times, listeners compensated for some missing points and frequency of listening helped listeners have a synoptic view of the listening text. This sequence of listening tasks helps listeners promote their knowledge of listening topic.

In phase two, the instructor guided the listeners to organize their notes and share them with their peers in a group. The notion of group working helped the listeners grow confidence in their listening ability. This sharing of thoughts about the listening input assisted the listeners to infer the intended message. This explicit sequence of listening tasks was aligned with sharing, discussion and evaluation recommended by Goh and Taib [11]. This explicit sequence of listening tasks was foreign to most of the listeners and they learnt some of the missing segments from sharing notes with their peers. This strategy-based approach helped them remove their potential opposition and realized why they were doing what they were doing and involved the listening lessons.

In phase three, listeners began to discover all the missing segments or points through matching their notes with the original texts. This discovery learning caused the listeners to grow self-management and draw a distinction between how far and how close their comprehension was to the original texts. Then, a good lesson learnt by the listeners is to experience learning from their errors, which enable them to take further risks in learning. Finally, after receiving enough knowledge of listening topic, sharing the thoughts with peers, and exchanging the notes, the listeners listened to the same listening texts for the fourth time. Then, they assessed their performance and compared with previous times to consider their own progress. This listening progress drawn from the strategy-based approach aided the listeners to deal with their future listening texts strategically.

4.4. IELTS Listening Tests. The instrument to assess the listeners' listening performance in the pretest and posttest was practice IELTS listening tests. IELTS listening tests developed by Scovell, Pastellas, and Knobel [14] consist of four components each with ten questions. Like the nature of listening lessons, IELTS listening tests focus on daily conversation, public speech, academic discussion, and academic lecture. The listeners listened once to the pretest and posttest as it is allowed to listen once in their midterm and final in the language institute as well as the realtime IELTS test administration. Each pretest and posttest of listening took approximately 30 minutes and the listeners were given another 10 minutes to transfer their answers to their answer sheet. The pretest and posttest listening was first marked by reference to the answers specified by the listeners. To ensure maximum reliability, the exam board's regulations required strict adherence to the answer sheet form regarding both wording and spelling [15]. The listeners were rewarded a mark in any three-word phrase, where they missed a letter or misplaced a letter.

\section{Results}

Table 1 shows the listeners' performance as the percentage of correct answers for both the pretest and posttest. Based on the raw scores in the pretest, the listeners were divided into two groups: less-skilled and more-skilled listeners. Listeners whose raw scores fell more than one standard deviation below the mean were considered less-skilled listeners. There were seven less-skilled listeners: Farhad, Pirooz, Milad, Hossein, Fazl, Mir, and Vali. As such, listeners whose scores fell more than one standard deviation above the mean were considered more-skilled listeners. There were four moreskilled listeners: Reza, Mili, Zaki, and Rahim.

Table 2 presents more-skilled listeners' pretest and posttest performance. Of the four more-skilled listeners, only Reza decreased his listening performance in the posttest (by 7 percent). By contrast, the other three listeners, Mili, Zaki, 
TABLE 1: Pretest and posttest performance in percentage.

\begin{tabular}{|c|c|c|c|c|c|}
\hline Name & Pretest (\%) & Posttest (\%) & Name & Pretest (\%) & Posttest (\%) \\
\hline Reza & 85 & 78 & Mobin & 58 & 68 \\
\hline Mili & 75 & 76 & Hamed & 58 & 70 \\
\hline Zaki & 73 & 75 & Heidar & 55 & 75 \\
\hline Rahim & 68 & 72 & Moji & 55 & 76 \\
\hline Ebi & 65 & 78 & Roshan & 55 & 73 \\
\hline Rod & 65 & 80 & Sadeq & 60 & 68 \\
\hline Davood & 65 & 80 & Ali & 50 & 70 \\
\hline Akbar & 65 & 88 & Farhad & 48 & 68 \\
\hline Mohammad & 63 & 80 & Pirooz & 48 & 45 \\
\hline Taqi & 63 & 75 & Milad & 45 & 65 \\
\hline Kazi & 63 & 65 & Hossein & 45 & 60 \\
\hline Amir & 63 & 55 & Fazl & 43 & 55 \\
\hline Javad & 63 & 85 & Mir & 43 & 58 \\
\hline Jasem & 60 & 83 & Vali & 35 & 55 \\
\hline
\end{tabular}

TABLE 2: More-skilled listeners' pretest and posttest performance.

\begin{tabular}{lcc}
\hline Name & Pretest $(\%)$ & Posttest $(\%)$ \\
\hline Reza & 85 & 78 \\
Mili & 75 & 76 \\
Zaki & 73 & 75 \\
Rahim & 68 & 72 \\
\hline
\end{tabular}

TABLE 3: Less-skilled listeners' pretest and posttest performance.

\begin{tabular}{lcc}
\hline Name & Pretest $(\%)$ & Posttest $(\%)$ \\
\hline Farhad & 48 & 68 \\
Pirooz & 48 & 45 \\
Milad & 45 & 65 \\
Hossein & 45 & 60 \\
Fazl & 43 & 55 \\
Mir & 43 & 58 \\
Vali & 35 & 55 \\
\hline
\end{tabular}

and Rahim (by one, two and four percent resp.) increased their listening performance in the posttest.

Table 3 shows the less-skilled listeners' pretest and posttest performance. Of the seven less-skilled listeners, only Pirooz decreased his score (by three percent) in the posttest. The rest of the less-skilled listeners had an increase of at least 12 percent. Two of them (Farhad and Milad) had over 15 percent increase in the posttest listening comprehension test. The other less-skilled listeners Hossein, Fazl, Mir, and Vali made gains of $15,12,15$, and 20 percent, respectively.

In brief, the results show that of the seven less-skilled listeners, six listeners made a considerable amount of progress across the study. Of the four more-skilled listeners, three listeners made the progress across the study. However, the less-skilled listeners made more gains in the posttest than the more-skilled listeners did. The next section will discuss the results of this study.

\section{Discussion}

The results of this small-scale study showed that although the more-skilled listeners made progress slightly across the study, their progress was not as much as the less-skilled listeners gained across the study. The EFL listeners in this study were provided with the four listening lessons in a strategybased approach for the purpose of promoting their listening comprehension. The results showed that six of the seven lessskilled listeners made a considerable amount of progress in the listening comprehension across the study. To find out the reason why one less-skilled listener (Pirooz) did not make the progress, the researcher and the teacher invited him for an interview to ask for his general comments on listening lessons as well as the significance of listening in English language learning. Pirooz seemed to realize the significance of listening comprehension in language learning but mentioned that it was the first time he was taught the listening lessons. He got distracted and could not apply the strategies during the IELTS listening tests. He was also in short of time to use the strategies instructed in the listening lessons.

\section{Listening is one of the important skills in English that students have problems. Listening lesson is the best way to learn listening. When I was answering the questions, I suddenly got confused with the meaning of a difficult word, because I did not understand. I did not have time to answer the questions correctly.}

Putting more time on tracing down the meaning of an unfamiliar word hindered the listeners from using strategies to achieve more comprehension. Therefore, using a strategybased approach in listening comprehension requires listeners to have enough time to apply the strategies already instructed the sequential tasks. However, Vali made a dramatic progress, 20 percent, and was so happy with the way the listening lesson was presented. He stated that he has changed his mind of learning listening and suggested that the listening lessons helped him follow the listening input closely. 
I always thought that it takes ages [long time] to improve my listening. When I was taught the listening lesson and understood that it helped me score listening test better, I practised the listening lesson with other listening activities out of the class.

Mendelsohn [8] notes that a strategy-based approach does not change the guiding principle that the listeners must do a lot of listening and notes from the onset that not everything taught will be considered the form of strategy instruction. However, metacognitive instruction, using pedagogical cycle (predicting, monitoring, problem identification, and evaluation), provides less-skilled listeners with guides and support towards improving their listening comprehension ability [10]. Teaching metacognitive strategies using a strategy-based approach, such as advance organisation, directed attention, selective attention, and self-management, assisted the less-skilled listeners further than the moreskilled listeners in this small-scale study. This is because the less-skilled listeners thought they might not learn how to listen and the listening lessons helped them listen and practise listening activities strategically. The listening lessons using the strategy-based approach help listeners enlarge their working memory capacity to embrace more language chunks for future recall. Using the listening lessons with the pedagogical cycle for L2 listening helps the less-skilled listeners deal with authentic materials in an interesting way at the beginning of the strategy instruction [5]. This is because the less-skilled listeners benefit from the technique which Wilson [13] has called "discovery listening." This technique helps the less-skilled listeners directly to (1) focus on their precise listening problems, (2) find out the reasons for the problems, and (3) evaluate the importance of the problems. The less-skilled listeners' listening development should not go unnoticed in the classroom or this development goes awry after short time, as their cognitive knowledge is limited and needs to be developed. The instructor should highlight the less-skilled listeners' listening development and keep encouraging the listeners to reflect on their listening. The instructor encouragement assists the listeners to build up with listening bricks to form a good listening comprehension ability.

The results indicated that of the four more-skilled listeners, three benefited slightly from the metacognitive instruction across four listening lessons in a strategy-based approach. One of them, Reza decreased his score (by 12 percent) in the posttest. This might be because the moreskilled listeners relied more on the top-down strategies in the posttest or might be because of being on the horn of dilemma whether to use top-down or to use bottom-up strategies. Cross [10] suggests that the more-skilled listeners reach out a solid level of understanding of acting out the bottom-up and top-down strategies so the pedagogical cycle of metacognitive instruction does not have a noticeable impact on their listening comprehension. All the moreskilled listeners in this study acknowledged the benefit of the strategy-based approach for the listening lessons to develop their listening comprehension ability. They stated that listening is the basic and essential language skill and needs to be instructed like other skills (e.g., reading, writing, and speaking). Reza whose listening scores fell down (by seven percent) reflected that he did not practise the listening lessons adequately and thought he would always receive high score in listening tests. Part of his confidence in listening comprehension emerged from watching a lot of English movies.

Listening comprehension is more important than other skills... I watch many movies to improve my listening. It was the first time a teacher brought the listening lessons in the class and taught some strategies. I did not practise these strategies out of the class ... there was a difficult topic for the lecture in the listening. (Reza)

This listening lesson helped me find out some of my problems in listening comprehension. Now I can say I need to use strategies to improve my listening. (Mili)

The purpose of a strategy-based approach is to seek for the essential need to implement needs analysis and shows what needs to be taught and where the listeners are in terms of their proficiency level [12]. The listening lessons in this study helped the listeners as Mili states above to realize that to improve listening comprehension, they require, first to know the cause of the listening problems and then using strategies in a sequential way to solve them. This sequence of solving listening problems through strategy use leads to better listening performance.

The results of this study support those of studies [5, $10,11]$ suggesting that metacognitive instruction based on pedagogical cycle improves the listening comprehension ability of less-skilled listeners. By contrast, the results of this study showed that more-skilled listeners had a slight increase in the posttest, though one of them decreased his scores in the posttest. The result of this study indicated that the less-skilled listeners benefited more from the strategybased approach instructed for four listening lessons than did the more-skilled listeners. In addition, this study is different with the previous studies in terms of (1) listeners' language proficiency, (2) listening materials used for instruction, and (3) measuring the listening performance. First, the listeners in this study were Persian adult EFL with a highintermediate level, whereas the listeners in studies $[5,10$, 11] involved Japanese advance, Chinese ESL, and French high-beginner/low-intermediate, respectively. Second, the listening materials used in this study were only aligned with IELTS listening component contents (daily conversation, public speech, academic discussion, and academic lecture). In contrast, study [10] used BBC television news items, and studies $[5,11]$ utilized a variety of listening texts for the listeners in the classroom. Finally, the tool used to assess the listeners' pretest and posttest performance for this study was practice IELTS listening tests, whereas the studies above used standardized teacher-made tests, which were in parallel with the listening materials used for the metacognitive instruction. The results show that despite 
the slight increase in the more-skilled listeners, the lessskilled listeners in this study made noticeable gains in listening comprehension instructed based on the strategybased approach. Like previous studies discussed previously, listeners in this study attempted to recognize their listening problems, shared their thoughts with peers to discover a solution, and finally evaluated the outcomes of their listening comprehension. Therefore, a strategy-based approach potentially helps listeners in general and specifically the lessskilled listeners to increase the awareness of their listening improvement. Metacognitive instruction is a strong means to facilitate listening development and strategy awareness.

\section{Conclusions and Implications}

This small-scale study used the content of IELTS listening and examined seven less-skilled and four more-skilled listeners in the EFL context. The results provide some empirical support for the notion that metacognitive instruction using a strategy-based approach of advance organisation, directed attention, selective attention, and self-management can be helpful for guiding and assisting less-skilled listeners in developing their listening comprehension ability. In particular, the results suggest that the less-skilled listeners can benefit more than more-skilled listeners from such a strategybased approach. If the fact is accepted that less-skilled listeners need some further pedagogic support to improve listening comprehension ability, a classroom curriculum needs to be revised to add sequential tasks of listening lessons to explicitly instruct this basic skill in the classroom. Teachers in the EFL classrooms can use a strategy-based approach to L2 listening, which makes authentic materials more accessible for listening. This approach makes learning for less-skilled listeners more interesting and relevant to the purpose of the classroom.

\section{References}

[1] T. Lynch, "Academic listening in the 21st century: reviewing a decade of research," Journal of English for Academic Purposes, vol. 10, no. 2, pp. 79-88, 2011.

[2] J. H. Flavell, "Metacognitive aspects of problem solving," in The Nature of Intelligence, L. B. Resnick, Ed., pp. 231-236, Lawrence Erlbaum Associates, Hillsdale, NJ, USA, 1976.

[3] A. L. Wenden, "Learner development in language learning," Applied Linguistics, vol. 23, no. 1, pp. 32-55, 2002.

[4] J. E. Davidson and R. J. Sternberg, "Smart problem solving: how metacognition helps," in Metacognition in Educational Theory and Practice, D. J. Hacker, J. Dunlosky, and A. C. Graesser, Eds., Lawrence Erlbaum Associates, Mahwah, NJ, USA, 1998.

[5] L. Vandergrift and M. H. Tafaghodtari, "Teaching L2 learners how to listen does make a difference: an empirical study," Language Learning, vol. 60, no. 2, pp. 470-497, 2010.

[6] C. Goh, "Metacognitive instruction for second language listening development: theory, practice and research implications," RELC Journal, vol. 39, no. 2, pp. 188-213, 2008.

[7] L. Vandergrift, "The comprehension strategies of second language (French) listeners: a descriptive study," Foreign Language Annals, vol. 30, no. 3, pp. 387-409, 1997.
[8] D. Mendelsohn, Learning to Listen: A Strategy-Based Approach for Second Language Learner, Dominie Press, San Diego, Calif, USA, 1994.

[9] J. Field, "Finding one's way in the fog: listening strategies and second-language learners," Metacognition Learning, vol. 9, no. 1, pp. 29-34, 2000.

[10] J. Cross, "Metacognitive instruction for helping less-skilled listeners," ELT Journal, vol. 65, no. 4, pp. 408-416, 2011.

[11] C. Goh and Y. Taib, "Metacognitive instruction in listening for young learners," ELT Journal, vol. 60, no. 3, pp. 222-232, 2006.

[12] D. Mendelsohn, "Learn how to listen using learning strategies," in Studies on Language Acquisition: Current Trends in the Development and Teaching of the Four Language Skills, U. J. Esther and A. Martínez-Flor, Eds., Studies on Language Acquisition, pp. 75-90, Walter De Gruyter, Berlin, Germany, 2006.

[13] M. Wilson, "Discovery listening-improving perceptual processing," ELT Journal, vol. 57, no. 4, pp. 335-343, 2003.

[14] D. Scovell, V. Pastellas, and M. Knobel, 404 Essential Tests for IELTS General Training Module, Adams \& Austen Press , Sydney, Australia, 2004.

[15] J. Field, "The cognitive validity of the lecture-based question in the IELTS listening paper," IELTS Research Reports, vol. 9, pp. 17-65, 2009. 

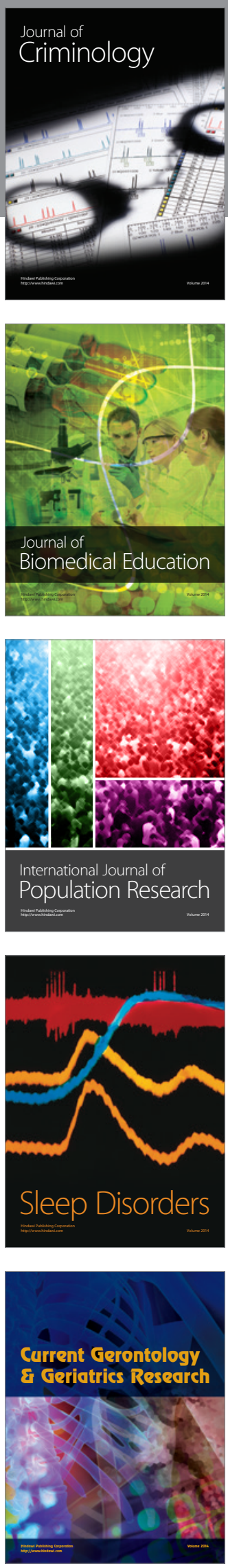
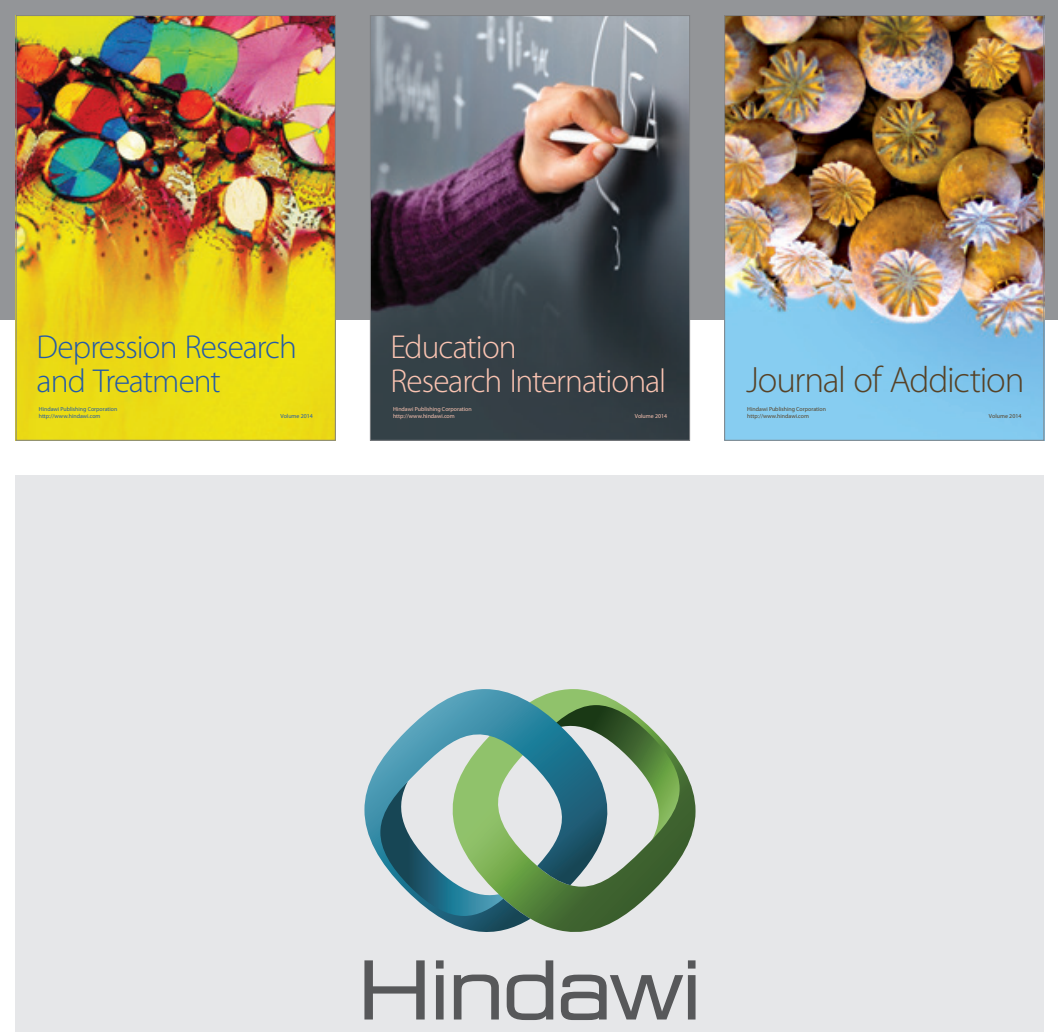

Submit your manuscripts at

http://www.hindawi.com

Child Development Research
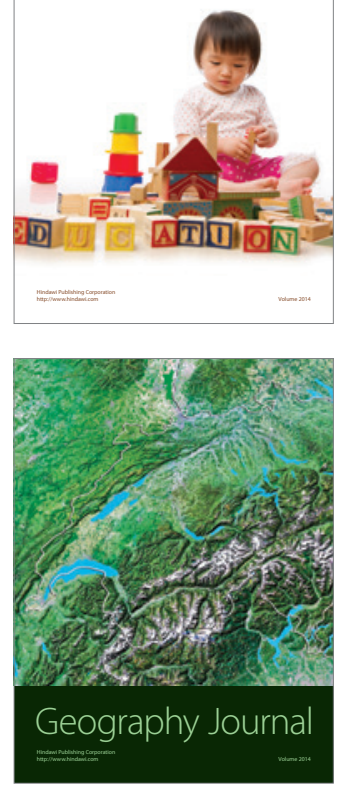

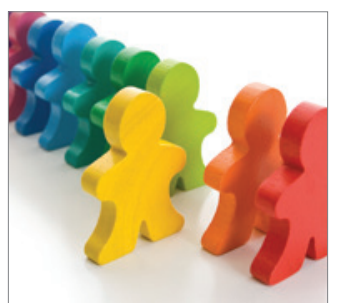

Autism

Research and Treatment
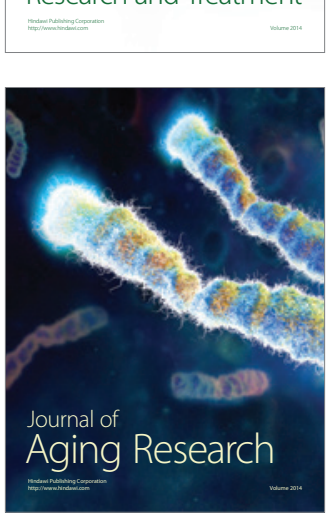
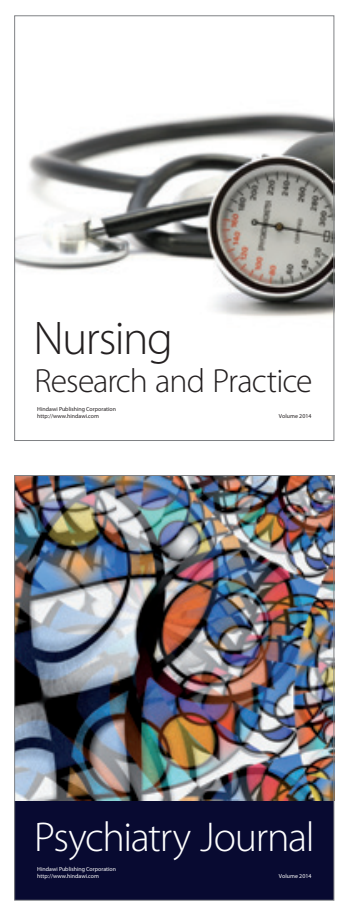
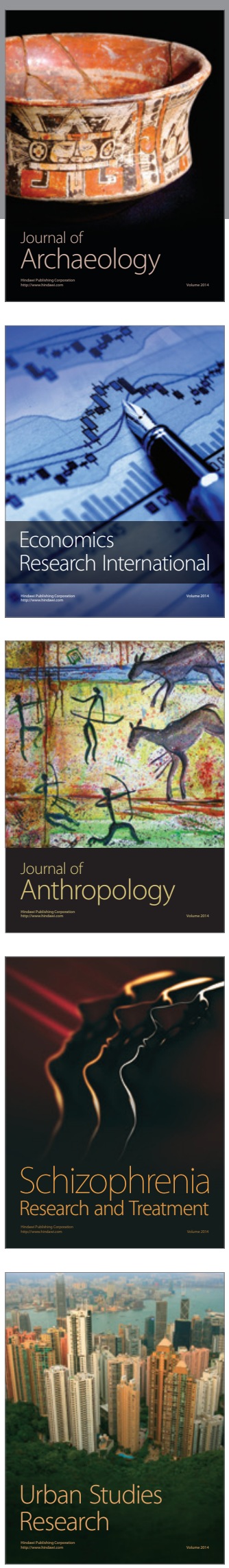